\title{
CA19-9 が高值を示した耳下腺腫瘍例
}

\author{
篠原 尚吾1)・八木 伸也1) ・佐藤 進一1) \\ 小形 哲也 2 - 津嘉山朝達 3 )
}

\section{Elevated CA19-9 Level in a Patient with Parotid Tumor}

\author{
Shogo Shinohara, Nobuya Yagi, Shin-ichi Sato and Asatatsu Tsukayama \\ (Kurashiki Central Hospital) \\ Tetsuya Ogata \\ (Kobe Central Hospital)
}

\begin{abstract}
A parotid tumor was found in a 69-year-old female patient with a high serum CA19-9 value. Several treatments were administered: chemotherapy, operation, postopertive chemotherapy and radiation. The serum CA19-9 value decreased with the reduction of the tumor volume, by stages as each coursed therapy. Histological examination revealed "carcinoma (adeno-squamous carcinoma) in a pleomorphic adenoma." Immunopathological examination of the specimen proved that the high level of CA19-9 originated in the adenocarcinoma part of the tumor. We discuss the usefulness of CA19-9 serum values as a tumor marker of salivary neoplasms.
\end{abstract}

Key words: salivary neoplasm, tumor marker, CA19-9

はじめに

CA19-9 (Gastrointestinal Cancer-Associated Antigen 19-9) は1979年 Koprowski らねとっ て開発された消化器癌関連抗原で結腸, 直腸癌 の培養株細胞 SW1116を抗原として得られる モノクローナル抗体で認識される，膵癌および 胆道系の癌患者の血清に, 高頻度に高値を示す. 特に, 早期発見の困難な脺臓癌の発見や, 再発 のフォローには非常に有用である。CA19-9 は 免疫組織学的には膵癌, 大腸癌, 胃癌の腫瘍細 胞内の汪か正常の膵管，肝内胆管や前立腺，耳 鼻咽喉科領域では唾液腺や気管腺に局在する事
が知られている213).

今回我々は術前血清 CA19-9 が高值を示した 耳下腺癌の症例を経験した。術後の経過と腫瘍 組織の免疫学的検討により, CA19-9 が耳下腺 癌由来であると判断し得た. CA19-9 と唾液腺 腫瘍の関係につき, 若干の文献的考察を加えて 報告する。

\section{症例}

症例 : 69歳, 女性.

主訴：右耳下部腫瘍.

既往歴：15歳時虫垂炎，20歳時肋膜炎に罹患 した他特記すべき事なし。

1）倉敷中央病院耳鼻咽喉科

2）神戸市民病院耳鼻咽喉科

3）倉敷中央病院病理検査科 
家族歴：特記すべき事なし。

現病歴: 平成 3 年 12 月頃より右耳下部にしこ りがあるのを自覚していたが放置していた。平 成 4 年 6 月頃より増大し始め, 側頸部にもしこ りができ始めたので，近医の勧めもあり平成 4 年. 9 月 19 日倉敷中央病院耳鼻咽喉科を受診した。

初診時所見：右耳下部に $35 \times 30 \mathrm{~mm}$ の弾性 硬の腫瘤を触孔た。腫瘤は周辺組織と癒着して 括り可動性は不良であった。そ汪か，右上内 深頸部にリンパ節が径 $20 \mathrm{~mm}$ ほどの腺塊を形 成しており，末た右外深頸部にも小豆大のリン パ節を 2 個触知した. 顔面神経麻㽻を含め, 腫 瘍によると思われる神経症状は認められなかっ た。耳下部の腫瘍の針生検にて, Class Vの診 断を得たため，平成 4 年 9 月 21 日入院となった。 また近医より CA19-9 が高值であるが CEA は 正常範囲であること, 腹部超音波検査にて肝胆 萃に異常がなからたことなどの報告を受けた。

入院時所見：CT では, 右耳下腺内に辺縁不 整で, 造影剂により不均一に造影される長径約 $35 \mathrm{~mm}$ の腫瘤を認めた。 下顎後静脈は腫瘍に よる压排のためか造影されて扣らず，深葉由来 であるか浅葉由来であるかの区別はつかなかっ た(図1).

また右上深頸部，外深頸部にリンパ節腫脹を 認め触診上の所見と一致した。ガリウムシンチ では腫瘍部に一致して取り达みを認めたが，他 の部位に異常な集積はみられなかった。骨シン チ, 胸部単純レ線では異常所見は見られなかっ た。血液検查では末梢血, 生化学とも異常を認 めなかった，腫瘍マーカーは，SCC 抗原は正 常範囲でめったが CA19-9 は，263.9 U/ml（正 常值50以下) と著明な高值を示した。

治療は neo-adjuvant chemotherapy 飞従い, まずシスプラチンと 5-FUによる化学療法を施 行した。即ち，第 1 病日目にシスプラチン 75 $\mathrm{mg}$ を点滴投与し，第 2 から第 5 病日目までに $5-\mathrm{FU}$ を 1 日 $750 \mathrm{mg}$, 計 $3000 \mathrm{mg}$ 持続点滴し た. 化学療法の効果は, 頭頸部癌取扱い規約の 基準によると PR とは言えないが，触診および
画像診断上明らかな縮小を認めた。化学療法後 3 週目に測定した，血清 CA19-9の值は 137.9 $\mathrm{U} / \mathrm{ml}$ と約半分に低下していたが，まだ正常よ りかなり高い值であった. 平成 4 年11月 6 日（化 学療法後 4 週目) に右耳下腺全摘術之右頸部郭 清術を施行した。原発巣は耳下腺浅葉にめり腫 瘍は顔面神経と接していたが，浸潤はなく容易 に剥離できた。患者の QOL を考光耳下腺は全 摘したが，顔面神経は温存した。上，中，下内 深頸部持よび外深頸部のリンパ節に最大のもの

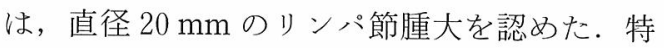
に上内深頸部のものは斜角筋, 頸椎の横突起な どにも癒着を来して扤り鋭的に剝離せざるを兄 ない状態であった。

耳下腺原発栄の病理診断の結果は, carcinoma (adenosquamous) in pleomophic adeno$\mathrm{ma}$ (多形腺腫内癌)の診断であった。内深頸り ンパ節群，外深頸リンパ節群にとれぞれ16/17, $3 / 3$ のリンパ節転移を認めた。 術後 2 週目に測 定した血清 CA19-9 の值は, $44.3 \mathrm{U} / \mathrm{ml}$ と著し く低下した。術後の経過は良好であったが，手 術所見より十分な safety margin を得ていない ので, 化学療法 (CAP 療法; 第 1 日目シスプラ

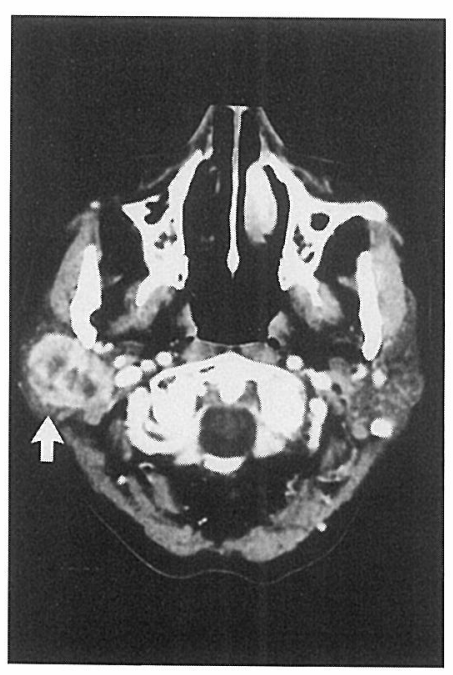

図 1 造影 CT 写真 右耳下腺内に腫瘍を認める。 
チン $75 \mathrm{mg}$, 第 2 日目サイクロフォスファミド $200 \mathrm{mg}$ ，第 3 日目アドリアマイシン $40 \mathrm{mg}$ ) と, FAR 療法を併用した放射線療法(リニアック 50 $\mathrm{Gy}$; $2 \mathrm{~Gy} / \mathrm{day}$ ，このうち FAR 療法併用 $18 \mathrm{~Gy}$ ) を追加した。放射線療法終了時の血清 CA19-9 の值は， $11.9 \mathrm{U} / \mathrm{ml}$ であった。CT および触診 上 $\mathrm{CR}$ を確認し, 平成 5 年 2 月 24 日退院となっ た。

治療の経過と血清 CA19-9 值の推移を, 図 2 に示す。この図上り，血清 CA19-9 值は腫瘍の 量をかなり忠実に反映していると考光られた.

病理組織所見：腫瘍は腫瘍巣を形成する扁平
上皮癌様の部分と，明らかな腺管様形式を示す 腺癌様の部分から構成され，腺扁平上皮癌の所 見であった（図 3 )。をた腫瘍の一部に明らかに 混合腫瘍の部分があり, 癌組織への移行がみら れ，もともと混合腫瘍 origin であったと考光ら れた(図 4 )。免疫組織学的検索は, $\mathrm{ABC}$ 法 (Avitin-Biosin-peroxidase Complex 法)により 行なった。 ホルマリン固定された組織を，抗 CA19-9 抗体(東レ富士バイオニクス社製)を用 いて $4^{\circ} \mathrm{C}$ に一晚染色した。その結果, 腫瘍 の一部腺癌様の部分に染色される部分がみられ， CA19-9 が，この腫瘍 origin であると判断され

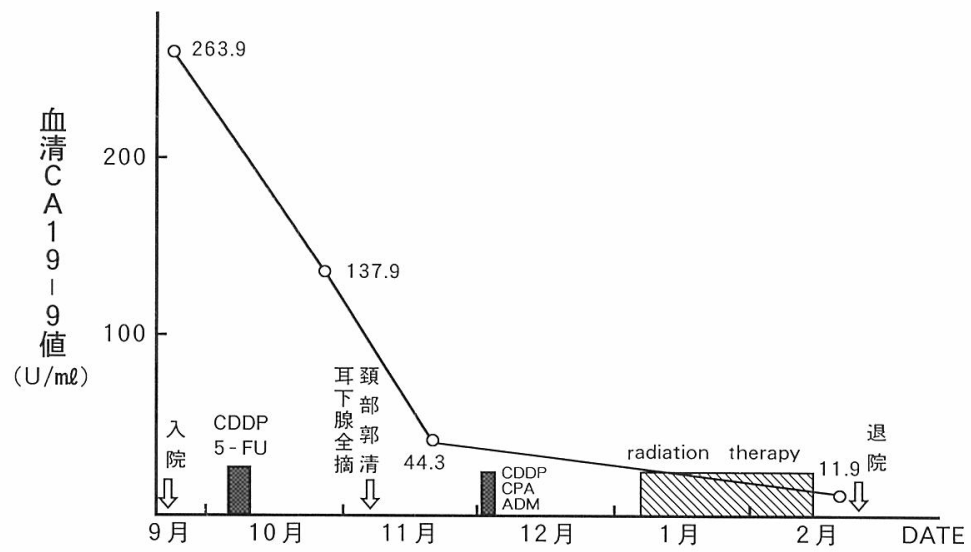

図 2 治療経過と血清 CA19-9 值の推移

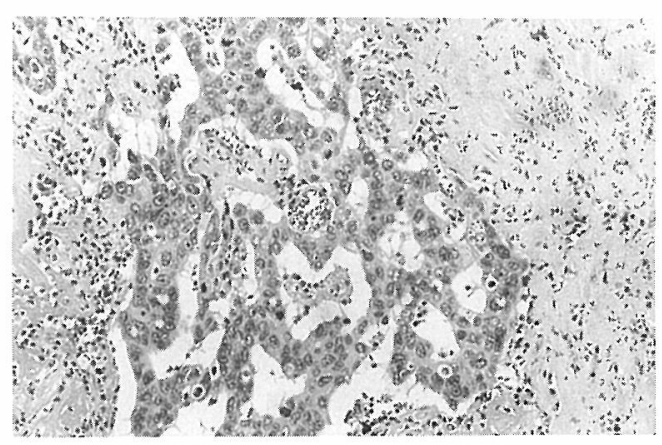

図 3 病理所見 (HE 染色, 100倍)

腫瘍の一部を示す。明らかな腺管様構造を示す, 腺癌様の部分である。この他の部位には, 扁平上 皮癌様の所見もあった。

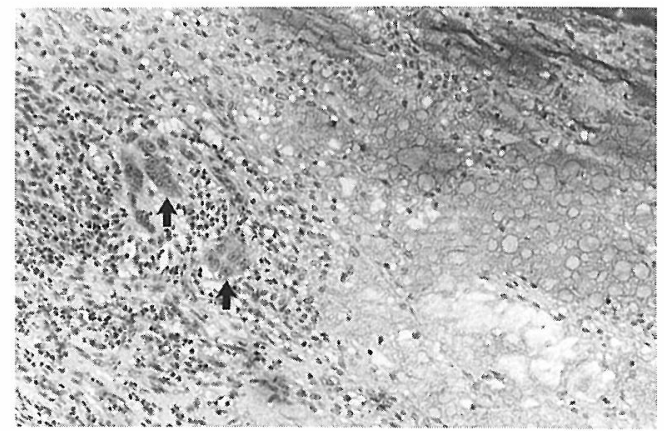

図 4 病理所見 (HE 染色, 100倍)

右側に, 粘液腫様の良性混合腺腫の組織がみ兄, 癌組織への移行(矢印)が確認される. 
た（図 5)，混合腺腫の部分，扁平上皮癌様の部 分, 扣よび正常耳下腺部は染色されなかった。 また，リンパ節転移の部分も腺癌様の部分は染 色された。

\section{考按}

CA19-9は，1979年 Koprowski ら ${ }^{1)}$ によって 発見された腫瘍マーカーである。この腫瘍マー カーはヒ卜結腸, 直腸癌の培湌株細胞を抗原と して得られるモノクローナル抗体で認識される 腫瘍関連抗原で, 膵癌, 胆道系の癌に利用され ている。とくに膵癌に拈いては約 $90 \%$ の陽性率 でかなりの高值を示し，臨床症状が現れにくく 診断の困難なこの腫瘍の早期発見や術後の観察 に役にたっている4). 血液型物質 (Lewis 型抗原) を母体とする異常代謝産物であるとされて拉 り5)，正常組織でも膵管，肝内胆管，気管腺， 前立腺, 并して唾液腺に存在することが知られ ている2)3)，唾液腺に関して言えば，唾液の中 にもCA19-9 が検出される6) ことより，組織内 では腺房細胞に局在する事が予測される。実際 飞免疫組織学的に唾液腺内での CA19-9 の局在 について詳細に検討したのは，1986年の藤木7) が最初であり，それによると導管の内容物と粘 液性腺房細胞に CA19-9 の存在を認めている. また小唾液腺の粘液性腺房細胞に特いて局在 し，大唾液腺のそれには汪とんど存在しないと

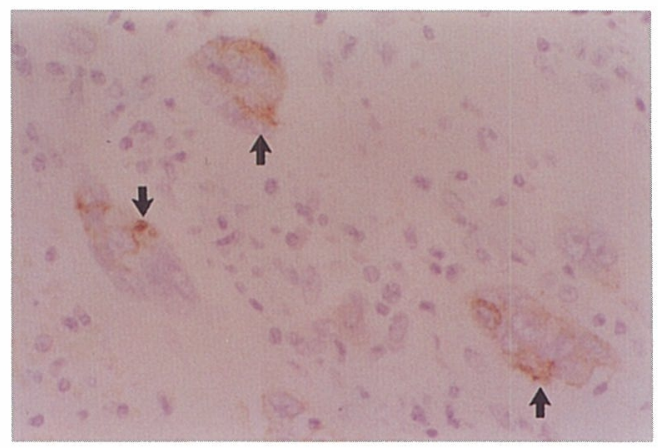

図 5 病理所見

(ABC 法による免疫組織染色，400倍)癌細胞の細 胞質拉よび細胞膜の一部が，褐色に染色されてい る.（矢印）
の事である。これを裏付けるように草間8 は， 全唾液内にCA19-9を検出し得た健常人に対し て，耳下腺唾液内（お乞らく，Stensen's duct より直接採取したものと思われる)には 1 例も CA19-9を検出できなかったと述べ，唾液内に 検出されるCA19-9 はそのほとんどが小睡液腺 で産生されるのであろらと推測している。

以上のような結果から考光ると, 正常耳下腺 にCA19-9は，核とんど存在しないといらこと になる。しかし藤木ら7)は，睡液腺由来の様々 な腫瘍内の CA19-9 の局在を調べ，多形腺腫14 例中 10 例, 粘表皮腫12例中 5 例, 腺様蛮胞癌 8 例中 6 例，ワルチン腫瘍 1 例中 1 例にその局在 を認めたとしている。とく多形腺腫のらち 1 例は耳下腺原発であり，まわりの正常組織には CA19-9 は全く存在しなかったのに，腫瘍の充 実性または腺管様構造を構成する細胞のごく一 部にその局在を認め，腫瘍化によりその酵素系 が変化したためであろうと推測している．以上 のように, CA19-9 は唾液腺組織の腫瘍化によ って産生される可能性があり，かつ当症例のよ らに血清值を正常值以上に上昇させることもあ ることより唾液腺腫瘍の腫瘍マーカーとなり得 る可能性がある。過去の文献を渉猟してみると， 唾液腺腫瘍と血清 CA19-9 の関係につき検討し たのは，我々の調べた範囲では，1988年の Gustafsson ら ${ }^{9)}$ の報告 1 例のみである. Gustafsson ${ }^{9)}$ らは125例の頭頸部の腫瘍につき，CEA，CA50, CA19-9 の 3つの糖鎖腫瘍抗原の血清内濃 度を測定した。それらの症例の中には，21例の 良性唾液腺腫瘍と18例の悪性唾液腺腫瘍が含ま れていた．血清 CA19-9の上昇を見たのは，良 性唾液腺腫瘍では21例中 0 例，悪性のそれでは 18例中 4 例であった(粘表皮癌 2 例, 腺様藥胞 癌 1 例, 腺房細胞癌 1 例)。 また悪性耳下腺腫 瘍の CA19-9 濃度の平均值は，良性耳下腺腫瘍 の平均值より明らか涼かったとしている，彼 らの報告は免疫組織学的検討に欠けるものでは あったが，悪性腫瘍と良性腫瘍に明らかに差が あり，良性腫瘍では 1 例も血清 CA19-9 値は上 
昇を来さないといら点は興味深い。我々も4 例 の良性多形腺腫と 1 例のワルチン腫瘍に対し, 術前血清 CA19-9 を測定したが，いずれも正常 範囲であったばかりか，そのらち 3 例について は術後も血清 CA19-9 を測定したが，術前值と 全く変化がなかった。しかしさきに述べた藤木 ら ${ }^{7)}$ の報告では，良性多形腺腫にもCA19-9 は， かなりの高頻度で存在している．以上の事より CA19-9 は, 唾液腺の腫瘍化により元来存在し なかった細胞の酵素系に変化を与産生される こともあるが，良性腫瘍では産生されたとして も血清内の值を上昇させるまでにはいたらない。 覀性腫瘍となり細胞の代謝が活発になると, 血 清内に異常值として検出されることもあり得る, と推測される.

結論として, CA19-9 は術前の腫瘍の質的診 断の一助として役立つ可能性は示唆されるが, むしろ当症例のように, 術前高值を示せば腫瘍 の量を忠実に反映するため, 治療の効果判定や 再発のチェックとして役立つであろう。いずれ にせよ，本邦ではいままでほとんど唾液腺腫瘍 の腫瘍マーカーとしての価值を検討されていな い. 今後の検討が待たれる.

\section{結語}

1 ) 術前 CA19-9 が，高值を示した耳下腺癌 の 1 例を経験した。

2 ) 術後の免疫組織学検討に上り, CA19-9 が腫瘍由来であることを証明した。

3 ) CA19-9の, 唾液腺腫瘍に打ける腫瘍マ ーカーとしての価值につき検討した.

\section{参考文献}

1) Koprowski H, Herlyn M, Steplewski $Z$, et al : Specific antigen in serum of patiens with colon carcinoma. Science 212: 53 55, 1981.
2) Atokinson B, Ernst $C$, Herlyn $M$, et al : Gastrointestinal Cancer-Associated antigen in immunoperoxidase assey. Cancer Res 42 : 4820, 1982.

3) Arends JW, Verstynen C, Bosman FT, et al : Distribution of monoclonal Antibody-Defined Monoclonal-Gangliosied in normal and cancerous human tissue; an immunoperoxidase study. Hybridoma 2 : 219 229, 1983.

4) 吉川敏一, 西田康一, 谷川真理, 他 : 各種消化 器癌に打㚈る糖鎖抗原 CA19-9 の検討一種 及 の腫瘍マーカーとの比較一. 医学の歩み 128 : 373 375, 1984.

5) Magnani J, Brockhaus M, Smith D, et al : A monosialoganglioside is a monoclonal antibody defined antigen of colon carcinoma. Science $212: 55 \sim 56,1981$.

6) Brockhaus M, Wysocka M, Magnani JL, et al : Normal salivary mucin contains the gastrointestinal Cancer-Associated antigen detected by monoclonal antibody 19-9 on the serum mucin of patients. Vox Sang $48:$ 34 38, 1985.

7) 藤木 敏：腫瘍関連抗原に関する研究 -1 . 唾液腺扣上び唾液腺腫瘍にお汁るCA19-9 の局 在について一. 日大医学 $60: 185 \sim 191,1986$.

8）草間 薫 : 腫場関連抗原の検討 -2 . CA199 の酵素免疫測定法の検討と唾液の成績につい て一. 日大医学 $60: 702 \sim 709,1986$.

9) Gustafsson H, Franzen L, Grankvist K, et al : Glycoprotein tumor markers in head and neck neoplasms ; a consecutive study on CA-50, CA 19-9, and CEA. J Cancer Res Clin Oncol $114: 394 \sim 398,1988$.

$\left(\begin{array}{l}\text { 原稿受付: 平成 } 5 \text { 年 } 6 \text { 月 } 22 \text { 日 } \\ \text { 原稿採択 : 平成 } 5 \text { 年 } 8 \text { 月 } 27 \text { 日 } \\ \text { 別刷請求先 : 篠原尚吾 } \\ \text { 个 } 710 \text { 倉敷市美和 } 1-1-1 \\ \text { 倉敷中央病院耳鼻咽喉科 }\end{array}\right)$

